\title{
Banuta Rubess: New Languages for Performance
}

\author{
Natalie Rezua
}

\section{Banuta Rubess: des nouveaux langages de performance}

Cet essai examine une stratégie déployée pour transformer les représentations des corps des femmes dans la performance théâtrale traditionelle. Dans Boom, Baby, Boom!, Banuta Rubess (dramaturge de Toronto) explore le jazz comme un modèle de performance qui déborde les limites d'un théâtre orienté sur le texte verbal. La stylisation des mouvements des personnages est accentuée par la mise en scène de Susan MacKenzie qui était, lors des représentations de la pièce, une véritable chorégraphie.

For Julia Kristeva, foreignness and familiarity are significant elements in creative expression. The situation of the subject either within the dominant discourse or outside it will determine the possibilities for communication and presentation, as in Kristeva's linguistic example of the stranger denied recourse to her mother-tongue. Initially, expression in the foreign language is constrained, and the speaker uses it for its "bare rhetorical strength" (Kristeva 21). The attainment of fluency in the new language is difficult, because it requires decoding "like algebra or musical notations" (Kristeva 32). On the other hand, such linguistic circumstances, which seem to deny spontaneity, can also be highly productive and liberating for the foreigner, who "belongs to nothing" and for whom a sense of "weightlessness in the infinity of cultures and legacies" is the source of an "extravagant ease" of enabling innovation (Kristeva 32).

Such a freedom from tradition as Kristeva conceives in terms of verbal language, may be found in feminist discourses of theatrical presentation. Feminist playwrights, actors and directors, speaking through the existing theatre's "foreign language" discover new means of dramatic and theatrical expression which challenge some traditional modes of presentation. Banuta Rubess's work is an outstanding example: as playwright and director she demonstrates how a feminist discourse may be more than merely a foreigner's use of 
existing dramatic and theatrical "languages" hierarchies but may invent new and liberating idioms for the stage.

As an active proponent of genderization of theatre, attempting to solve the problems that this presents for women as actors and directors, Banuta Rubess is in the forefront of contemporary Canadian theatre practice. Accepting Kristeva's challenge of "explicitly, obviously, ostensibly occupying the place of the difference" (Kristeva 42), Rubess repudiates not only the verbal and thematic clichés of women-as-victims, or women as survivors, but also the theatre iconography that accompanies them in all its postural, gestural and scenic forms.

Rubess's radical dramaturgy displaces an old hierarchy of literaryverbal signs and its theatrical realization using a visual-physical mise en scène that asserts female presence and, at the same time as she emphasizes this presence and also as a means of doing so, Rubess introduces an original visual vocabulary. This vocabulary stems from a process of stylization constituted by analogies between sister arts in the present case jazz and choreography. In Boom, Baby, Boom! jazz becomes a model for both the verbal and performance texts. The rhythmic beat and the jargon of the late fifties jazz era become the inspiration for scenographic design, dance-like choreography, the verbal rhythms and even the character portrayals. Jazz is thematized as the improvisatory mode of the young woman who is running away from the social constraints of her cultural ethos and experimenting with a "foreign" expression as a new modus vivendi.

Rubess's method in Boom, Baby, Boom! is a development from her earlier work with the collective creation This is for you, Anna in which clichés of women behind the headlines were theatrically explored. The limited images of a person's life fixed in police mugshots and sensationalizing newspaper photographs were used as the points of departure for scenic structure, movement sequences and dialogue. In this way the collaborators emphasized the dehumanization of women not only by criminal abuse but by subsequent interrogation. The Anna project frustrated audience expectations of a play which would explain, by way of dramatization, why Marianne Bachmeier shot Klaus Grabovsky in the courtroom, while he was being tried for the murder of her daughter. Instead of a more conventional characterization of figures embroiled in violence, four female performers dressed in simple black dresses represented a fragmented composite of Marianne on stark white platforms. Reinforcing this overall 
photographic motif in the scenography was the actual framed photo of a young girl. It was placed on a refrigerator standing on the upstage platform as a constant and visually dominant insistence on the real absence - the deadness - of the Anna whom the verbal text, by reference and naming, made an illusory presence.

Photography always excludes significant peripheral information and, in such documentary forms as the mugshot, ruthlessly re-contextualizes and devitalizes the subject. That all representations falsify in some such way was made explicit by the final sequence of the play. One of the Mariannes poured a glass of milk for the imaginary Anna, but this moment was not subjected to "photography." Real milk continued to pour from the pitcher, overflowing the glass and spilling onto the floor. Even when the lights went to black and the figure of the mother was no longer seen, the sound of spilling milk continued, as if stubbornly defying the representational conventions. It was left to the audience to reconcile its understanding of the Marianne who committed the murder and Marianne the bereaved mother at some profounder level than that of the given images of these figures.

In Boom, Baby, Boom! Rubess takes the historically minor roles allocated to women in the jazz scene of the time - the roles of waiters and girlfriends (Rubess 1990, 67-67) - as her point of departure for a re-envisioning - by means of an exploration of the musical medium and its expressive analogies - of the meaning of women's experience in the clubs. The depiction of the jazz scene of the late 1950s in Toronto is linked, through the central character, to another cultural phenomenon of the period - the post-war influx of immigrants, of whom this young woman is one. As Rubess aphoristically puts it, the action of the piece is "beatnik meets ethnic" (BBB 65). The beatnik is a musician liberated from classical form into jazz improvisation: the ethnic is in flight from the rigidities of a transplanted Latvian culture. One of the structural features of Rubess's mise en scène distinguishes the characters who can enact, or at least appreciate, improvisation from those who are dependent on a more premeditated form.

Austra Mednis is the 21 year old Latvian-Canadian who escapes from her engagement party to seek a cultural refuge in "The House of Hambourg," Clem Hambourg's jazz club. For Austra the club is a place where, "nothing has ever happened...no airplanes, no armies, no camps - " where "a New Canadian goes to feel old" (BBB 70, 71). What she is fleeing are the dreams and expectations of her fiancé, Aivars Putvejins, and their ethnic community: "a little Latvian 
island," which they will help populate and which is to be a piece the "jigsaw puzzle" of Canada (BBB 67). Putjevins' allegiance to Latvian music rules out jazz for him and the incompatibility of this couple, hearing such different rhythms, is definitively figured on the dance floor.

Situated somewhere between the Latvian couple is Jekyll the naive young Canadian poet-cum-artist-cum-musician-cum-drug-dealer. $\mathrm{He}$ occasionally entertains Clem's patrons, performing his own bongo poetry and mouthing the anti-war anxiety of Allen Ginsberg. Jekyll, however, forsakes the expressive freedom of jazz and "The House of Hambourg" to hide himself in the corporate culture of the $\mathrm{CBC}$ - the kind of cultural integration that Aivars aspires to, but from which he is excluded.

Marilyn Bercovich's set design for Boom, Baby, Boom! was part of the jazz presentation, improvising a "House of Hambourg" setting, without attempting to reconstruct it on stage. For the première at the du Maurier Theatre Centre, Bercovich took advantage of the second storey gallery to suggest a cross-sectional view of the club. On the main floor, the four piece jazz band occupied half the stage: on the other side the suggestion of the club was continued by means of a freestanding doorway and a small round table. Upstage, behind the drums, and in full view of the audience, a stairway led to the gallery. This space was dedicated to the activities of Clem's wife Ruthie-sewing and fitting costumes for the Victory burlesque. For the scenes set by Rubess in "Norm's Grill," the all-night diner where recorded rock and roll dominates the air waves, Bercovich had a stand-up coffee bar which was brought, as needed, into a cross aisle just behind the café tables, which were in the auditorium. Rubess's Latvian scenes were located either near the round table, or in the gallery - never centre stage.

The process of Austra's second migration - out of the Latvian community - was conveyed in Reg Bronskill's costume designs: a traditional Latvian ensemble, a 1950s flouncey blue dress for the engagement party, and the beatnik uniform of black trousers and sweater. This triadic sequence expressed the three possible attitudes to being Latvian in Canada not only visually but also, and more significantly in terms of the wearer's freedom of movement, as rendered in Susan MacKenzie's beat-inspired choreography. In her Latvian folk costume Austra was almost as well-behaved as her community could wish, her physical movements relatively subdued; in her party dress, 
Austra was freer to the point of transgression, climbing out of windows and beginning to pick up the jazz beat. In the club, the dress contributed to the gawkiness of her experimentation with the new rhythm; at the third stage, in beatnik black, Austra began to improvise in sync with her surroundings, rhythmically.

In the production's opening scenes, Rubess made the classical music synonymous with the traditions that Austra wishes to escape. Austra, her fiancé and her sister Laila, Clem, Jekyll and Ruthie were seated as though part of an anonymous audience listening to a rendition Beethoven's Moonlight Sonata, but they were also a somnambulistic little chorus, mimicking the rhythmical, impassioned swaying of the pianist with their torsos and heads. As the jazz band took over, with its "Jekyll" theme, these anonymous figures forsook unison for animated, idiosyncratic enactments of their personal scenarii: Jekyll, moving to the strains of the saxophone, in his role of young artist, begged money from the crowd at the House of Hambourg (the audience); Austra, in her party dress, wandered around the stage, as if through the city, experiment with the unaccustomed movements of crouch, lean, pivot, and leap, inspired by the beat of the jazz piano and drums; while Aivars in his black hat, holding a picture of Austra, crossed the stage, searching the city for his missing fiancée to the steady beat of the bass; Clem followed the piano rhythm and resumed his position of M.C. in the club. Directed by the steady beat of the bass, Ruthie seeks refuge in her sewing room and Laila assumes her position at the command post at the family home. Not surprisingly, Laila, Aivars and Ruthie who are not animated by the jazz beat as are the other figures cannot make sense of the improvised action. The choreography and the music rendered a chaotic totality of mutually uncomprehending subjectivities.

Austra's physical presence in, and disruption of, a Canadian community, is initially presented as an illogical disruption of an otherwise conventional scene. Ruthie's criticism of the band's drummer who "plays in four when Bela Bartok taps it out in 5/8, 7/8 all the time" $(B B B 61)$ is consistent with the choreography that separates Austra from the concurrent action on stage. In the first scene of the play, just before assuming the pose of a concert listener, Austra had literally dropped to the stage from the gallery. At this point, she grabs the arm of the unsuspecting Clem and provides him with unsolicited personal information about her past. Although her appearance is an encapsulated image of her bravado, it is also an absurd interruption of Clem's 
review of his private photo gallery of classical musicians and composers. Clem points to "photos" of Chaliapin, and Stravinsky, but Austra gives her credentials in terms of contemporary literature: "I have read Henry Miller and Jack Kerouac and Allan Ginsberg and Jean-Paul Sartre. And I am an atheist. And I don't care if I am a virgin" (BBB 56). Her arrival is weirdly out of time. She has a tune and a story, but the stage narrative has yet to catch up with her.

In her second out-of-time entrance, Austra leaps on stage, as if tumbling through a window. Significantly, this second intrusion into the action is just after Clem's introduction of the jazz musicians and, in fact, is a thematic segue of her past life with her new love of jazz: "Oh, I like windows. Sometimes I climb out of my bedroom window at night. There is a magnolia tree which always hits me in the face. Once in the war I pushed through a window on a train because a man looked hard and said "devuchka" which is Russian for "girl but really it means I'll huff and I'll puff and I'll" ... Picking up her tune, Clem finishes the sentence: "blow your house down" (BBB 57). Austra's nonsequiturs here are made intelligible in subsequent scenes. When $\mathrm{Clem}$ and Austra actually meet and talk - as opposed to being presented in separate and interrupted realities - and they lie smoking the "green tea stuff," they have come together as the verbal, visual, and physical equivalent to a successful jam session.

Similarly in a later sequence, Rubess relied on choreography rather than explicit dialogue to present the emotional undercurrents of the action. When Austra considers returning to Aivars after her harrowing experience as a would-be drug dealer, her thoughts, glossed by the jazz ensemble, are enacted on stage: considering the security that marriage with Aivars would provide, Austra thinks back to her engagement party, imaginatively (as the audience understands the action) she changes back from her beatnik outfit to her party dress, all the while fending off taunts from Jekyll. Then, as Aivars is projected from Austra's imagination into her reality, the two of them are transported to the dance floor.

Their pas de deux is an expression of their differing perceptions of their relationship. Aivars attempts to embrace Austra according to ballroom etiquette, but in Austra's imagination the couple is dancing to the jazz ensemble's "Austra I love you." She continually slips out of his grasp, jerking away and collapsing to the floor. Ann-Marie MacDonald's portrayal of Austra was the actorly equivalent to an instrumental jazz riff coming into conflict with the regimentation of 
classical music. Eventually Austra imagines that Aivars resolves his frustration with their apparent incompatibility by picking her up and carrying her off stage. Rubess repeatedly employs such musical and choreographic switches in the representational code to express the subject's ambiguous feelings about escape from, and return to, the Latvian community.

Rubess's dramaturgy and mise en scène further distinguish between spontaneous and prescribed behaviour by developing an analogous distinction between live and recorded jazz. In the third "set," several very brief scenes set in the club are intertwined with vignettes of immigrant life. In one of these, Jekyll angrily reads the commentary on the jacket of a recording of Buddy Holly, while the record itself plays in the background. He ridicules the impossible claim to the recording's "brilliant true-to-life fidelity" (BBB 69) of a dead musician. Simultaneously, Austra and Aivars come from the shadows, where they have been dancing silently during Laila's monologue of immigrant nostalgia. They occupy the aisle location, used for "Norm's Grill," dancing a weird combination of jive and Latvian folk frolic to the very Buddy Holly recording that Jekyll mocks. Austra, dressed in her Latvian costume appears to be in a state of seeming prejazz consciousness. This example of the complex scenic montage, in which the intervals and rhythms defy the consecutiveness usually associated with a narrative in the dramatic theatre and seem to belong to the sister arts of jazz and modern dance, is characteristic of Rubess' work here overall, of its powerful originality with respect to the very foundations of her theatrical expression.

In the following scene, Austra mourns Buddy Holly's death but Laila and Aivars hardly notice this. Rubess illustrates Austra and Aivars's incompatibility when along with Laila they begin to sing the Latvian song "Lai Dzivo Sveiks." During the song Austra creeps away, by the end of which Aivars, filled with nationalistic sentiment, proposes to Austra, but without realizing that she is absent. In this case Austra's detachment begins verbally, but is made clear musically. Aivars's not being "with it" is figured in the character's relation to the physical presentation signalled by the choice of music. Finally, we see Laila, left alone, shouting down Jekyll's rendition of the beat poem "Session" by "f.a.c." (BBB 69) and throwing at him articles, representing the domesticity that Austra is fleeing. The scene is brought to an abrupt end when Austra reappears on the stage and utters the enigmatic, "My name is Austra Mednis. You must excuse me." This, as we 
shortly learn is another version of Austra's entrance to the club, one in which Rubess presents the audience with a tremendously compressed version of Austra's segue from folk frolic to jazz beat, reiterating, emphasizing and clarifying her method of an interpretative transposition from scene and dialogue to the rhythms and restatements of movement and music.

In another scene jazz is transposed from a purely musical presentation into a verbal idiom which stands for instrumental virtuosity. There appear to be three statements of the episode set in "The House of Hambourg," in which Jekyll persuades Austra, who is waiting on him there, to sell drugs in "Norm's Grill" in order to help Clem out financially. The restatements are not replays, however, but a compressed view of the development of Jekyll's relationship with Austra. In each version Jekyll plays on Austra's façade of being cool, until cool means being capable of selling the drugs without attracting attention to herself. The choreography of the three restatements tends towards a progressive realism, while the dialogue progressively absorbs more verbal jazz jargon, becoming thus more and more congruent with the accompanying jam session. Jekyll, as jazz equivalent, is revealed not only through the language, but also by the saxophonist's shadowing of the poet as he plays. In the initial statement, Jekyll and Black Hat lie on the floor when Austra brings Jekyll's cappuccino; in the restatement, Jekyll leans against the piano, while Black Hat stands behind him and Austra lounges against the door; in the third version, Austra and Jekyll sit at the same table, become lost in each other's eyes, excluding the whole world, and the saxophonist resumes his position with the band. Beginning tentatively with the inquiry "who's your old man" in the first sequence, Jekyll is progressively emboldened until, by the last version of their encounter he can urge Austra to throw caution to the wind because "soon, we're all going to go pop, man, boom baby ... I mean the big blast, the ultra-fungoid, the End!" (BBB 65).

There is a comparable presentation of the characters' attitude towards Clem in these restatements. When Clem approaches while they are speaking realistically, Austra and Jekyll drop silent, but as they adopt the jazz idiom, the musicians who are not part of the jam session physically, and not musically, squeeze Clem off the stage. Rubess's physicalization of the jazz by this act of the musicians is a particularly original aspect of the mise en scène.

Rubess's use of jazz is significantly different from some other 
recent experimentations with jazz in the theatre. Although Boom, Baby, Boom! incorporated some details from the history of jazz, by using 1959 as the date for the action, the performance did not seek to present a historical image of jazz. Most significantly, although the jazz musicians remained on stage for much of the performance they were not fully integrated as characters. In other productions this insistence on the integrity of live jazz, as a component separate and distinct from a dramatic text, has not always been a factor. Take for example Mr. Jelly Roll by Larry Cox which integrated Jelly Roll Morton's New Orleans jazz as interludes into a dramatization of the musician's biography. This production frustrated jazz aficionados and theatre spectators alike. Necessary Angel's Coming Through Slaughter was similarly problematic in its attempt to bring Michael Ondaatje's inventive prose equivalent to jazz into the theatre. The production allowed Toronto's theatre regulars an evening in the tap room of Toronto's infamous Silver Dollar and Richard Rose, the director, seems to have hoped that by evoking the atmosphere of the smoky, dark caverns where Buddy Bolden blew his trumpet, he could transpose Ondaatje's linguistic virtuosity into a straight forward historico-biographical account. The explicitness of theatrical performance in this case hampered a verbally experimental script.

Tapestry by Alexis DeVeaux and Unfinished Women Cry in No Man's Land While a Bird Dies in a Gilded Cage by Aishah Rahman use jazz as a parallel text. The first of these plays juxtaposes Jet's law studies with her lover's dreams of playing the saxophone like John Coltrane. In Unfinished Women Rahman intertwines Charlie Bird Parker's physical decline with the final stages of the pregnancy of a young woman in a home for teen mothers. When Wilma screams in the throes of delivery, Parker's saxophone wails its last note as darkness descends upon the stage. In both cases, jazz is the distant metaphor of the characters' desires and does not approach the status of a foundational mode of presentation that Rubess accords it in Boom, Baby, Boom!.

This use of the musical sister art by Rubess is a highly discriminating and expressive exploration of the resources and potential of theatre. Boom, Baby, Boom! points to the larger issue of her mise en scène as a search for a dramaturgy which will discover distinctive methods of language and presentation that stem from re-envisioning of women theatrically.

More recently, in the summer of 1991, Rubess has addressed the 
question of intercultural performance once again in terms of translation that moves beyond the linguistic. In The Avenging Woman, mounted in collaboration with the Kabata Theatre of Latvia, Rubess and Neil Bartlett revived and explored a turn-of-the-twentieth-century work by the Latvian playwright Aspazija without attempting a word-for-word translation. Performances in Toronto were based on Aspazija's original Latvian text, the verbal component of which was conveyed by two figures who shadowed the characters and, at crucial times, reported, narrated, or spoke for them in English. The usual dependence on language was subverted by glossing the movement with only a few verbal interventions, rather than translating whole speeches.

In discussion of this experiment Rubess has remarked that choosing to leave the original Latvian as the language of performance opened up a tremendous opportunity to foreground and challenge the highly genderized theatrical signs that are usually concealed by the emphasis on a verbal text. In this instance, as in her earlier work, Banuta Rubess worked collaboratively to reconfigure the customary verbal and visual hierarchies and to articulate thus a female dramaturgy and theatricality.

\section{Works Cited}

Kristeva, Julia. 1991. Strangers to Ourselves. trans. Leon S. Roudiez. New York.

Rubess, Banuta. 1989. Boom, Baby, Boom!. In Canadian Theatre Reviezv no. 58, (spring 1989). The production under discussion is that directed by the playwright herself for the du Maurier World Stage Theatre Festival, June 5-8, 1988, at Harbourfront, Toronto. I am grateful to Banuta Rubess for lending me an archival videotape by means of which I was able to refresh my memory of the production.

Rubess, Banuta. 1991. "Gender Issues in the Theatre: A Panel of Theatre Professionals." May 27, Meetings of the Association for Theatre Research in Canada. Kingston, Ontario (not published). Rubess, Banuta. 1990. "Interview" by Rita Much in Fair Play: twelve women speak. Toronto: Simon \& Pierre. 